\title{
Assessing the Value Relevance of Goodwill Impairment Considering Country-Specific Factors: Evidence from EU Listed Companies
}

\author{
Enrico Laghi ${ }^{1}$, Marco Mattei ${ }^{1} \&$ Michele di Marcantonio ${ }^{2}$ \\ ${ }^{1}$ Department of Law and Economics of Productive Activities (DEAP), "La Sapienza” University of Rome, \\ Rome, Italy \\ ${ }^{2}$ Department of Statistical Sciences (DSS), "La Sapienza” University of Rome, Rome, Italy \\ Correspondence: Marco Mattei, Department of Law and Economics of Productive Activities, Faculty of \\ Economics, "Sapienza" University of Rome, St. Via del Castro Laurenziano, 900161 Rome, Italy. Tel: \\ 39-329-023-4091. E-mail: marcomattei@hotmail.it
}

Received: April 22, 2013

Accepted: May 23, 2013

Online Published: June 20, 2013

doi:10.5539/ijef.v5n7p32

URL: http://dx.doi.org/10.5539/ijef.v5n7p32

\begin{abstract}
The objective of this paper is to assess the value relevance of goodwill impairment losses with reference to the listed companies operating in the European Union area during the period from 2008 to 2011. We investigate whether the information of goodwill impairment is a relevant factor that influences the investment decisions of market operators, testing the statistical significance and the explanatory power of a multivariate regression model widely known in literature for estimating market stock prices of companies using balance sheet data, including goodwill impairment. To this end, we select two samples of companies: a first group of listed companies operating in United Kingdom from 2008 to 2011 that is similar to the one used in previous researches on the same topic; a second group of firms operating in France, Germany, Italy, Portugal, Spain and United Kingdom that reported a goodwill impairment loss for the same period, to extend the analyses also to other economic contexts. Each sample is split into further subsamples differentiated in terms of country of domicile, reference year, industry sector and level of relative importance of goodwill impairments. We propose some changes to the original model, including a new explanatory variable aimed at considering also country-specific differences. The analyses of subsamples show that goodwill impairment is significant only for two years (2008 and 2009) and for French listed companies across all periods. Therefore, further investigation should help in understanding these differences that could be related to country-specific factors such as cultural, environmental and regulatory aspects.
\end{abstract}

Keywords: goodwill, impairment test, IAS-IFRS, value relevance, country-specific factors

\section{Introduction}

In recent years, the crisis that has affected the world's economies as also produced significant effects on Financial Reporting. In addition, the introduction of IFRS (International Financial Reporting Standards) 3, Business Combination, (IASB, 2004a) has changed the accounting rules for assets and liabilities in a Business Combination. In this context the academic experts have largely focused on issues related to the accounting treatment for intangible assets. In particular, the academic literature has explored the accounting treatment for Goodwill. This study has investigated the change introduced by international accounting standards that, as is known, prohibits the amortization of goodwill. Instead, they requires impairment testing be performed annually or more frequently if events or changes in circumstances indicate that the asset might be impaired.

Different and prior studies provide empirical evidence that the amortization approach to goodwill is based on an arbitrary time period. So, this approach fails to provide useful information to the users of financial statements and instead adds "noise", making it harder for investors to use the earnings measure to predict future profitability (e.g., Jennings, LeClere and Thompson, 2001; Moehrle, Reynolds-Moehrle and Wallace, 2001).

In view of the above and in order to improve the information content related to the economic value of acquired goodwill, the IASB (International Accounting Standards Board) chose the impairment approach. However, many concerns of preparers, users, academics and some members of the IASB itself have been raised also in regard to this approach, because it leaves significant room for managerial discretion, interpretation, judgment and bias 
(Massoud and Raibom, 2003). It is worth mentioning that the IASB has recently decided to start a post-implementation review (also "PIR") of IFRS 3, which according to the current work plan of the IASB, should have been initiated in 2012. The IFRS handbook identifies two main objectives for the PIR:

1) to review the important issues that had been identified as contentious during the development of the pronouncement;

2) to consider any unexpected costs or implementation problems that have been encountered.

In order to support the IASB during the PIR of IFRS 3, the EFRAG (European Financial Reporting Advisory Group) and OIC (Italian National Standard Setter), in partnership with the ASBJ (Accounting Standards Board of Japan), are conducting a research project about the accounting treatment for goodwill and the possible solutions to the issues, for example: improvement of the existing rules of the impairment test; reintroducing the amortization of goodwill in addition to the impairment test; improving the disclosure currently required by IAS 36 (as pointed out by the ESMA [European Security of Markets Authority] in the report of January).

Furthermore, the academic literature has focused on how, in financial statements, the balance sheet substance of many companies is constituted by the large (excessively so) and growing presence of so-called intangibles (Lev and Zarowin, 1999), especially the amounts of goodwill. Many concerns have been raised in this regard, also in relation to the possibility of managers implementing manipulative policies (Degeorge, Patel and Zeckhauser, 1999; Marquardt and Wiedman, 2004; Barua, Legoria, and Moffitt, 2006; Betty and Weber, 2006; Ramanna, 2008; Markarian, Pozza and Prencipe, 2008, Watts, 2003).

Thus, the concern about the real economic value of goodwill has increased, also as a consequence of the growing number of business combinations that have occurred in recent years. As s consequence, the same concern extends to the related validity of the balance sheet value for those companies that carry goodwill in their financial statements.

Finally, accounting theory has not expressed a unanimous opinion as to the best way to treat goodwill in financial statements (Miller, 1973; Ma and Hopkins, 1988; Colley and Volkan, 1988; Barret, et al., 1991), while shareholders are even less able to identify the effects caused by the accounting for this controversial item (Duvall, et al. 1992).

Within this debate, some studies have been conducted about the influence that accounting information, particularly on goodwill, can have for users and investors. In addition, some of these studies have focused their attention on the value relevance of goodwill impairment reported following the adoption of IFRS 3. Here, for value relevance, we refer to what was said by Barth and Clinch (1998) and Barth (2000) that "an accounting entry has value relevance when it is associated with some measure of the market value of the company".

The objective of this paper is to assess the value relevance of goodwill impairment losses with reference to the listed companies operating in the European Union (EU) area during the period from 2008 to 2011 (the "Period"). We chose the EU because, since 2005, with the transition to international reporting standards, all firms listed on the main markets of the EU have had to discontinue amortizing goodwill and account for it using IFRS 3.

We investigate whether the information on goodwill impairment losses is a relevant factor that influences the investment decisions of market operators. We do so by testing the statistical significance and the explanatory power of a multivariate regression model widely known in literature for estimating stock market prices of companies using balance sheet data. To this end, we select two samples of companies: a first group of listed companies operating in United Kingdom from 2008 to 2011 that is similar to the one used in previous studies aimed at testing the reference econometric model, in order to assess the robustness of the results using data from recent years; a second macro-sample of firms operating in France, Germany, Italy, Portugal, Spain and United Kingdom that reported a goodwill impairment loss for the same period, in order to extend the analyses also to other economic contexts. Each sample is split into further subsamples in order to verify the technical assumptions underlying the model and to assess the value relevance of goodwill impairment losses across countries of domicile, reference years, industry sectors and levels of relative importance of goodwill impairments compared to the carrying value of goodwill at the end of the previous year. We propose some changes to the original model, including the addition of a new explanatory variable aimed at considering also the sovereign default risk of the country where each company is domiciled.

Our analyses evidences that the model yields good results in terms of basic statistics, such as the F-statistic, adjusted $\mathrm{R}^{2}$ and the variance inflation factor. With reference to the two macro-samples, also the T-statistics show a high individual significance of the regressors, including the one relating to goodwill impairments and the new one relating to the sovereign default risk of each country. However, additional tests show that some basic 
assumptions of the ordinary least squares regression method are not verified, as we have detect problems of non-normality of residuals and misspecification. Furthermore, the analysis of subsamples evidence the fact that the validity and the effectiveness of the model vary significantly across countries, sectors and groups of firms characterized by different levels of relative importance of goodwill impairments. Finally, we notice that in most cases, the goodwill impairment variable is non-significant.

On this point, we note that accounting theory has developed some studies that show how different accounting practices and, generally the accounting culture, are influenced by country-specific factors that should be considered when value relevance analyses are developed (Alia and Branson, 2011; Gray, 1988, Jaggi and Low, 2000; Nobes, 1998). We consider these studies in our work because, reasonably, although we conducted the analysis on a sample of firms that have adopted the IAS-IFRS system, the circumstance that these firms have different country domiciliation and different country stock market should affect the results in terms of value relevance of goodwill impairment.

This study contributes to the existing literature by providing new evidence about the effective value relevance of goodwill impairments in recent years for a wide range of countries, sectors and categories of companies that operate in the EU area. We also detect a new, significant explanatory variable for estimating the stock market price of companies using a model that is widely known in literature, performing in-depth econometric analyses in order to assess its validity. In general, in most cases the results of the multivariate regressions analyses raise questions about the effective value relevance of goodwill impairments.

The importance of our work lies in the fact that we extended the findings of previous studies introducing a statistically-significant country-specific factor into the model, that is a market measure of nations' default risk. Furthermore, we tested the validity of the model considering a wider and varied range of companies, differentiating the analyses for multiple subsamples identified by goodwill and non-goodwill firms, by country we consider the most relevant EU nations -, by sector, by year and by relevance of goodwill impairment in relative terms. Finally, we performed in-depth econometric analyses that are not commonly used in literature in order to assess the statistical significance and explanatory power of the model, thus making more robust our conclusions about the value relevance of goodwill impairment for EU listed companies.

The remainder of this paper is organized as follows: Section 2 presents the evolution of legislation in EU concerning accounting for goodwill after the introduction of the IAS-IFRS system. Section 3 provides a brief theoretical background on value relevance and its relationship to goodwill; Section 4 describes the dataset and the methodology used to develop the research; Section 5 presents the descriptive statistics and the empirical results; finally, Section 6 offers some concluding remarks.

\section{Background}

Accounting for goodwill is a controversial issue, particularly regarding its subsequent measurement (Amodeo, 1960; Ardemani, 1957; Capaldo, 1998; D’Ippolito, 1963; Guatri, 1957; Laghi, 1994; Paoloni, 1988; Zanda, 2007).

In the EU, before the adoption of the IAS-IFRS system, listed companies prepare their financial statement in compliance with local GAAP. Now, under the new system, they must also prepare the financial statement in compliance with the IAS-IFRS system. So, before the introduction of the new system, goodwill at initial recognition was capitalized in the balance sheet as an intangible asset and for its subsequent measurement amortized over a maximum time period, which for Italy and United Kingdom tended to be a maximum of twenty years. (Note 1)

In more detail, in Italy, under the local GAAP, the goodwill capitalized in the balance sheet as an intangible asset had to be systematically amortized, preferably with straight-line criteria over its useful economic life, which for best practice could not exceed twenty years. Substantially, in Germany, GAS n. 4 (German Accounting Standard) provided for the same treatment: goodwill had to be amortized on a systematic basis over its estimated useful life. An amortization period in excess of five years could only be used in justified cases. Goodwill had to be amortized using the straight-line method unless another method more appropriately reflected the way in which the value of goodwill was depleted. Any changes to the systematic basis originally selected had to be justified. The recoverability of goodwill and the remaining useful life had to be reviewed at each year-end. In the case of an impairment of value, write-downs had to be recognized, or alternatively the remaining useful life had to be shortened ( $\S \S 27-35$ ). The Portuguese GAAP (Plano Oficial de Contabilidade - POC) was substantially consistent with Italian and German GAAP. They generally required that an intangible asset had to be amortized over its useful economic life. In particular for Goodwill, it was amortized over a maximum period of five years, unless a more extensive useful life (not exceeding 20 years) could be justified (POC, subsection 5.4.8; DC 12, 
DC 1). If the amortization period exceeded five years, the reasons for that longer period had to be disclosed (POC, Section 9, note 9).

Under the French GAAP (Plan Comptable), goodwill was linearly over its useful economic life (the maximum period is not specified) and, if there was evidence of impairment, an impairment test had to be performed. In addition, the consolidated goodwill had to be entered in fixed assets and amortized over a term which was required to reflect, as reasonably as possible, the assumptions adopted and objectives established and documented at the time of acquisition. Moreover, unfavourable material changes arising in the components used for determining the amortization were to lead to extraordinary depreciation or to modification of the amortization schedule, not to a provision for diminution in value. If favourable material changes occured, they are to lead to modification of the future depreciation schedule to the exclusion of any amortization written back.

Similarly, the UK local GAAP (Financial Reporting Standard n. 10) allowed goodwill to have a useful economic life of greater twenty years, or even an indefinite one, but only when it was expected to be capable of continued measurement. In particular, in accordance with FRS 11 Impairment of fixed Assets and Goodwill, where goodwill was regarded as having an indefinite useful economic life, it was not be amortized. If goodwill was not amortized, or if it was amortized over a period of more than 20 years, then an impairment review had to be performed each year to ensure that the carrying value of the goodwill did not exceed its recoverable amount.

Although Italian, Spanish, Portuguese, German, French and UK accounting rules and practice have converged gradually since 1978 due to the accounting Directives n. 78/660 (IV Directive) and n. 83/349 (VII Directive), the summary of the Local GAAP described above shows how for different countries that should be harmonized, there still exist different accounting treatment for various category of Business (such as unlisted companies, separate financial statement and etc.) that, probably, reflect the different accounting culture in the countries.

However, for the firms that are listed on the main stock markets, since 2005, as per the IAS/IFRS (in particular: IAS 36, Impairment Assets; IAS 38, Intangible Assets; and IFRS 3, Business Combinations), goodwill, as a good of indefinite useful life, is no longer amortizable but is subject to impairment testing. The impairment test, to be conducted annually and whenever there is an indication that the asset may have seen its value reduced, entails the comparison of the carrying value (in the financial statements) with the recoverable value, and, where necessary (where the carrying amount is greater than the recoverable value), requires a write-down of the goodwill.

In addition, according to IAS 36, goodwill acquired in a business combination should, from the date of acquisition, be allocated to each of the acquirer's cash-generating units, or groups of cash-generating units that are expected to benefit from the synergies of the business combination, irrespective of whether other assets or liabilities of the acquisition are assigned to those units or groups of units. Each unit or group of units to which goodwill is allocated should represent the lowest level within the entity at which goodwill is monitored for internal management purposes.

The impairment loss is first allocated to the goodwill of the cash-generating unit (group of units) before it is allocated to other assets within the unit (group of units) on a pro-rata basis, as long as it does not reduce any asset below the highest of its fair value less costs to sell, its value in use, and zero. The impairment loss is recognized immediately above the line in the section of income from continuing operations. Once recognized, IAS 36 prohibits the recognition of reversals of impairment losses for goodwill in subsequent periods.

Although IAS-IFRS system forces managers to perform annual goodwill impairment tests and, at a lower level, use a one-step test of impairment, it also provides the opportunity for accounting discretion by requiring managers to make a number of accounting choices.

So, if there are different accounting cultures, in addition to the opportunity for accounting discretion, there will probably be different interpretations and applications also for the same standard that in this present study is that of the IAS-IFRS system. These differences should be shown empirically when we study the value relevance using a regression model that is widely known in literature.

\section{Literature Review}

In this section, we summarize the concept of value relevance as used in accounting studies and give a brief overview of the main evidence relating to the value relevance of impairment of goodwill.

The measurement and reporting of intangibles has attracted keen interest from accounting researchers, prompted by the growing gap between the book value and market value of companies (Beattie 2005). Concerns have been raised because many intangibles are not recognized as assets, due in part to the conservative nature of asset recognition criteria and concerns for the reliability of contemporary accounting standards. As a consequence, 
entities investing in intangible assets characterized by high levels of uncertainty have a restricted capacity to recognize some intangibles as assets, and thereby have difficulty communicating relevant financial information to external parties (Oliveira, Rodrigues and Craig, 2010).

All of these events have led to a profusion of empirical papers that have analyzed the value relevance of traditional accounting variables in order to assess the usefulness of financial information to investors. This interest is justifiable given the generally accepted view that accounting figures are aimed at providing investors with relevant information for investment decisions (Dumontier and Raffournier, 2002). The trend of value relevance in traditional accounting measures has been widely explored (e.g., Brown, Lo, and Lys, T., 1999; Chen and Zhang, 2007; Collins, Maydew, and Weiss, 1997; Dahmash, Durand and Watson, 2009; Francis and Schipper, 1999; Goodwin and Ahmed, 2006; Lev and Zarowin, 1999; Papadaki and Siougle, 2007) and the value relevance of accounting information, including specific items of disclosure related to intangibles, has been questioned strongly (see Wyatt, 2008).

On the basis of the studies that, using the information content approach, report negative stock market reactions at the announcement of asset write-offs (Bartov, Lindahl and Ricks, 1998; Elliot and Shaw, 1998; Francis, Hanna and Vincent, 1996; Strong and Meyer, 1987), studies focusing on the value relevance of fair value estimates of goodwill impairment are concluded that the goodwill impairment losses are relevant (AbuGhazaleh, Al-Hares and Haddad, 2011; Bens and Heltzer, 2004; Lapointe-Antunes, Cormier and Magnan, 2009; Xu, Anandarajan and Curatola, 2011).

This study follows the above mentioned literature that adopts the association approach when examining the value relevance of goodwill impairment losses. However, being aware of the limitations of past research, this study differs from prior studies in three key aspects. Firstly, unlike previous research, this study focuses on IFRS 3 goodwill impairment losses reported in different countries that adopt the same accounting system but that have different accounting cultures. Secondly, in order to consider the country-specific factors, we introduce another explanatory variable into the model. Thirdly, this study performs different analyses:

1) with both firms that have recognized an impairment loss on goodwill (impairers) and firms that have not done so (non-impairers) as its sample for the empirical tests in order to better examine the "net benefits" of the impairment-only approach under IFRS 3 and in order to mitigate the limitations that were shown by Ramanna in 2008;

2) only with impairers as its sample for the empirical tests in order to verify whether there are relevant differences across countries.

More specifically, the objective of this paper is to assess the value relevance of goodwill impairment losses, under the accounting treatment required by the IAS-IFRS standards, with reference to the listed companies operating in the EU area, but that have both a different country domicile and different stock market.

To this end, we consider (in a general sense) value relevance - a concept that is open to more than one interpretation (Francis and Schipper, 1999) and is most definitely complex - as being the capacity of financial statements to capture information capable of summing up the value of a company. This means (in a specific sense) that an accounting entry has value relevance when it is associated with some measure of the market value of the company (Barth and Clinch, 1998; Barth, 2000). Among these measures of value, accounting literature generally uses the price or yield expressed by the official markets, thereby implicitly positing a certain degree of efficiency of such markets (Kothari and Zimmerman, 1995; Kothari, 2001; Aboody, Hughes and Liu, 2002; Subramanyam and Venkatachalam, 2007). Moreover, price models that use the price level as a dependent variable are better than models that use price change or returns models in order to verify whether and how an accounting item is reflected in the firm's value (Barth, Cram and Nelson, 2001). In addition, these models are better for regression coefficient estimation (Kothari and Zimmerman, 1995) and provide better indications in terms of long-term linkages (Beaver, 2002). In essence, the function that sums up value relevance can be expressed as (Beisland, 2008):

$$
p=f(A I)
$$

where: $p$ is the share price that expresses the market value of the equity, and $A I$ is the accounting information. The latter may be of a book value type and of an earnings type (Ohlson, 1995).

Consistent with Ramanna (2008), AbuGhazaleh et al. (2012) - using a sample of 528 firm-year observations drawn from the top 500 UK listed firms for 2005 and 2006 - conducted a study that employs a multivariate ordinary least squares regression (proposed by Lapointe-Antunes et al. in 2009 for Canadian firms) to assess the value relevance of goodwill impairment losses following the adoption of IFRS No. 3 "Business Combinations". 
Empirical results reveal a significant negative association between reported goodwill impairment losses and market value, suggesting that these impairments are perceived by investors to reliably measure a decline in the value of goodwill and are incorporated in their firm valuation assessments. The study provides evidence consistent with the IASB's objectives in developing the impairment-only standard and reinforces the argument that, through IFRS 3, managers are more likely to use their accounting discretion to convey privately held information about the underlying performance of the firms. The two models differ only for the calculation mode adopted for determining the third explanatory variable relative to the measure of companies' profit, that in Lapointe-Antunes is defined as the "earnings before extraordinary items for the year in which the transitional goodwill-impairment test is completed".

For these reasons, in this paper, with some changes, we make an assessment about the validity of the proposed model by extending the analyses to other EU countries. This is because all the countries that we consider for the analysis, in addition to being the main countries of the EU, refer to the same set of accounting standards. In other words, all countries that we consider refer to the version of IAS-IFRS standards that is approved by the European Commission. The hypothesis that we try to verify is that the goodwill impairment item does not give, in absolute terms, relevant information for investors. In particular, we believe, consistent with other studies, that the differences both in terms of accounting practices, as the difference between de jure harmonization (harmonization rules) and de facto harmonization (harmonization practices), and in terms of country-specific factors such as legal, fiscal, cultural and political values (Ashiq and Lee-Seok 2000, Laghi 2006, Swanson, Singer and downs, 2007), can influence the empirical results both in terms of coefficient values and in terms of significance.

\section{Methodology}

\subsection{Data}

The model we present in this paper is tested using two macro-samples, both constituted by listed companies operating in the European area during the period from 2008 to 2011 (the Period).

The first macro-sample ("Sample 1") was determined in accordance with the main criteria used by AbuGhazaleh et al. (2012), in order to select a group of companies that are reasonably similar - except for some elements, including the reference dates, the companies' sector, the data sources and the Winsorization of sample observations, as better specified in the following - to the one they used to run their analyses. Our aim indeed is to test the validity of the model also for recent years' observations and to conduct further exams in order to verify whether the assumptions underlying the ordinary least squares (OLS) regression method are satisfied. Therefore, we consider all the United Kingdom companies that were listed on the London Stock Exchange at the end $\left(31^{\text {st }}\right.$ of December) of each year of the Period.

The second macro-sample ("Sample 2") is aimed at extending the analyses developed by AbuGhazaleh et al (2012) to other European nations, in order to verify whether there are relevant differences across countries in terms of the model's significance, explanatory power and parameter values. The chosen nations are the countries characterized by major relevance in Europe in terms of economic importance, as well as by particular (problematic) economic conditions observed in recent years: France, Germany, Italy, Portugal, Spain and United Kingdom. For each year of the Period, we consider the companies that at $31^{\text {st }}$ of December were listed on the following stock markets: Euronext Paris (France); XETRA, Frankfurt, Berlin, Düsseldorf, Hamburg, Hannover, Munich, Stuttgart (Germany); Borsa di Milano (Italy); Euronext Lisbon (Portugal); Madrid, Barcelona, Bilbao (Spain); London Stock Exchange (United Kingdom). Furthermore, unlike Sample 1, we retain in the sample only the companies whose goodwill impairment reported value is different from zero, thus excluding all of the observations for which the goodwill impairment is zero.

The logic underlying the use of these macro-samples is the following. Analyses on Sample 1 are aimed at testing additional properties and assumptions of the model proposed by AbuGazaleh et al (2012), but with some modifications. Although there are differences between reference samples and model structures (partly intentional), the use of a group of observations that is similar to the one they selected is motivated by the need to obtain results that are reasonably comparable to their findings. With Sample 2 we explore the significance of the model also for other European nations; we exclude non-write-down observations because, in our opinion, the objective of testing the significance of goodwill impairment decisions on stock market prices through a multivariate OLS regression model can be better reached by excluding the cases (which are the majority) in which goodwill write downs are zero.

For each macro-sample we identify also a group of subsamples according to the following criteria: i) industry sector; ii) country of domicile (only for Sample 2); iii) reference year (only for Sample 2); iv) percentage 
incidence of goodwill impairment at year $(\mathrm{t})$ on the amount of goodwill at year (t-1), labeled as "GI\%". The industry sector of companies was defined as a dummy variable in order to distinguish between financial firms (the "Financials") and non-financial firms (the "Non-Financials"), as disclosed by the Bloomberg Industry Classification System (BICS). The last criteria too is defined in terms of a dummy variable in order to distinguish between companies whose GI\% is less than or equal to $5 \%$ and the other firms whose percentage incidence is higher than $5 \%$. The analyses of subsamples are aimed at detecting eventual differences and at testing the robustness of the model's estimates across different sectors, geographic areas, years and groups of firms characterized by different levels of importance of goodwill impairments in relative terms. In this sense, among our subsamples, the Non-Financial sub-group of Sample 1 is the one that is most similar to the one used by AbuGazaleh et al. (2012).

Financial data for sample observations were collected on an annual basis at the $31^{\text {st }}$ of December of each year of the reference Period using the Bloomberg and Thomson Datastream databases. Companies' annual reports were also examined in order to check the correctness of the information obtained from the two databases. For each variable of the model (excluding the last one, that is the nations' CDS [Credit Default Swap] price), extreme values are excluded from the group of observations through a Winsorization procedure eliminating the values that are below the $5 \%$ percentile and above the $95 \%$ percentile. Finally, the observations that do not have the necessary data to apply the model are excluded.

Table 1 presents the structure of Sample 1 and Sample 2 organized by year and by country, showing the number of companies listed on the stock markets previously specified (the "Listed" firms) and the number of observations with available data selected through the search criteria (the "Selected" firms). The number of Selected companies included in Sample 1 (Sample 2) is 3,121 (835), out of 4,837 $(13,305)$ total Listed firms.

Table 1. Structure of sample 1 and sample 2

\begin{tabular}{llllllllll}
\hline Sample & & Sample 1 & \multicolumn{7}{c}{ Sample 2 } \\
\hline Year & Companies & $\begin{array}{l}\text { United } \\
\text { Kingdom }\end{array}$ & France & Germany & Italy & Portugal & Spain & United & Total \\
& & 1184 & 714 & 875 & 281 & 51 & 134 & 1184 & 3239 \\
\hline 2008 & Listed & 740 & 61 & 57 & 26 & 4 & 11 & 72 & 231 \\
& Selected & 1210 & 732 & 902 & 281 & 53 & 130 & 1210 & 3308 \\
2009 & Listed & Kingdom & \\
& Selected & 787 & 66 & 59 & 17 & 2 & 12 & 53 & 209 \\
2010 & Listed & 1202 & 748 & 914 & 281 & 53 & 132 & 1202 & 3330 \\
& Selected & 804 & 64 & 56 & 24 & 3 & 8 & 32 & 187 \\
2011 & Listed & 1241 & 768 & 941 & 281 & 54 & 143 & 1241 & 3428 \\
& Selected & 790 & 49 & 41 & 33 & 0 & 18 & 67 & 208 \\
Total & Listed & 4837 & 2962 & 3632 & 1124 & 211 & 539 & 4837 & 13305 \\
Total & Selected & 3121 & 240 & 213 & 100 & 9 & 49 & 224 & 835 \\
\hline
\end{tabular}

Description: This table provides the structure of Sample 1 and Sample 2 organized by year and by country, showing the number of companies listed on the stock markets specified in section 4.1 (the Listed firms) and the number of observations with available data selected through the search criteria (the Selected firms).

\subsection{Model and Variables}

The model applied by AbuGhazaleh et al. (2012) and Lapointe-Antunes (2009) - with the differences previously specified - is the following:

$$
M V A L_{i}=\alpha+\beta_{1} B V A L_{i}+\beta_{2} P T P_{i}+\beta_{3} E C V G W_{i}+\beta_{4} G I L A_{i}+\varepsilon_{i}
$$

where, for each reference year in which the goodwill impairment test is performed:

MVAL is the market capitalization of firm $i$ at $31^{\text {st }}$ December;

BVAL is the book value of equity minus the carrying value of goodwill of firm $i$ at $31^{\text {st }}$ December;

PTP is the sum of the pre-tax profit and the reported goodwill impairment loss of firm $i$ at $31^{\text {st }}$ December;

ECVGW is the sum of the carrying value of goodwill and the reported goodwill impairment loss of firm $i$ at $31^{\text {st }}$ December;

GILA is the reported goodwill impairment loss of firm $i$ at $31^{\text {st }}$ December, expressed as a positive number. GILA is zero for firms which do not report goodwill impairments. 
All the variables of the model reported in Equation (1) are deflated by year-end total ordinary shares outstanding. A correction for heteroscedasticity using White's heteroscedasticity-corrected variances and standard errors is also applied for estimating the model.

In our work we applied the model of AbuGhazaleh et al. (2012) - with the differences described below - using the sample observations described in Section 4.1 organized as unstructured panel data. The choice of that model was motivated by the broad consensus found in literature on its significance - both in statistic and economic terms -, as well as by the fact that the papers mentioned earlier conclude that goodwill impairment is value relevant, which is the object of our work for the EU context. Furthermore, the use of multivariate OLS regressions has two advantages: first, since it is a method widely known in literature, it requires brief technical explanations, thus leaving space for conceptual analysis of statistical results; moreover, it allows extensive testing to be performed to assess the statistical significance and the explanatory power of the model, with numerical or graphical test outputs that are easy to interpret. The main limit of the model is the assumption that the relation between the dependent variable and the group of independent variables is linear, as well as the other technical assumptions at the base of the OLS method. However, even though it is not possible to infer whether the hypothesized econometric structure is the best one to study the phenomenon under examination, the significance tests allow us to determine, in absolute terms, if those technical assumptions are verified or not, that is if the proposed model is valid or not.

However, besides the differences in the selection criteria of samples previously specified, we make the following changes to the original regression model of AbuGhazaleh et al. (2012).

Considering that annual financial reports for a given year $(\mathrm{t})$ are usually published at the beginning of the second quarter of the following year $(\mathrm{t}+1)$, for the MVAL variable, unlike the procedure followed by AbuGhazaleh et al. (2012) and by Lapointe-Antunes et al. (2009), we took as a reference the values as at $30^{\text {th }}$ April of year $(t+1)$. The rationale for this modification is that the value of the market capitalization at $31^{\text {st }}$ December cannot take into account information that is usually disclosed to market operators only three or four months after that date through the publication of financial reports. However, the time lag we propose for $M V A L$ allows us to correct the model taking into account the average temporal misalignment between companies' balance sheet information and market prices, thus allowing us to observe, on average, the impact of the release of accounting information on stock prices during the period in which financial statements are usually published.

A second modification to the original model is the addition of a further explanatory variable, that is a measure of the default risk of the country where each company operates. We expect that an increase (decrease) of a country's default risk as perceived by financial market operators determines a decrease (increase) in national stock prices, as a higher credit risk is perceived also with reference to the companies that operate in the same country. In order to quantify the sovereign credit risk perceived by financial market operators, we consider the price of 5 years-maturity Credit Default Swaps ("CDS") of each reference country at $30^{\text {th }}$ April of year ( $\mathrm{t}+1$ ) (the explanatory variable " $C D S N$ "). In fact, since $C D S N$ is a market price (as $M V A L$ ), the reference date must be set equal to the one chosen for the dependent variable, that is the $30^{\text {th }}$ April of year $(t+1)$.

We specify that for some observations the goodwill impairment at year $(t)$ is higher than the value of goodwill at year ( $\mathrm{t}-1)$, probably due to acquisitions and subsequent impairments that occurred during the year $(\mathrm{t})$. However, these cases constitute a very small share of the total number of sample observations considered in the analyses.

The final multivariate regression model we use in our work is the following (the "Model"):

$$
M V A L_{i}=\alpha+\beta_{1} B V A L_{i}+\beta_{2} P T P_{i}+\beta_{3} E C V G W_{i}+\beta_{4} G I L A_{i}+\beta_{5} C D S N_{i}+\varepsilon_{i}
$$

where, for each reference year (t), $C D S N_{i}$ is the market price at $30^{\text {th }}$ April of year ( $\left.\mathrm{t}+1\right)$ of the 5 years-maturity CDS of the country where company $i$ operates and the other variables are defined as for Equation (1) - except for the reference date of $M V A L$, that is the $30^{\text {th }}$ April of year $(\mathrm{t}+1)$.

We perform a multivariate OLS regression analysis for each selected subsample, correcting the Model for heteroscedasticity using White's heteroscedasticity-corrected variances and standard errors. We perform in-depth econometric analyses in order to test the OLS assumptions for each subsample, as well as to assess their significance and explanatory power across countries, sectors and levels of GI\%.

\section{Empirical Results}

\subsection{Descriptive Statistics}

Table 2 shows descriptive statistics for the variables included in the OLS regression model for both Sample 1 and Sample 2. We observe that GILA in Sample 1 has a minimum value equal to zero, as we considered all the 
observations of United Kingdom including the non-write-down ones; on the contrary, in line with the additional criteria used to select Sample 2, in the second group of observations the minimum value of GILA is higher than zero and equal to 0.002 . Differences between samples are also due to the Winsorization procedure used to remove outlier data, that was developed on the bases of percentile thresholds specific for each sample.

Table 2. Descriptive statistics of sample 1 and sample 2

\begin{tabular}{lllllllllll}
\hline Sample & \multicolumn{1}{l}{ Sample 1 } & \multicolumn{1}{c}{ Sample 2 } \\
\hline Variable & $\mathrm{N}$ & Mean & St. dev. & Minimum & Maximum & $\mathrm{N}$ & Mean & St. dev. & Minimum & Maximum \\
\hline MVAL & 3,121 & 1.268 & 1.618 & 0.018 & 8.008 & 835 & 11.518 & 16.099 & 0.375 & 85.610 \\
BVAL & 3,121 & 0.497 & 0.804 & -0.567 & 4.366 & 835 & 5.096 & 9.696 & -3.670 & 63.084 \\
PTP & 3,121 & 0.074 & 0.210 & -0.663 & 1.120 & 835 & 0.976 & 2.200 & -4.189 & 12.429 \\
ECVGW & 3,121 & 0.239 & 0.438 & 0.000 & 2.485 & 835 & 3.889 & 5.315 & 0.059 & 37.619 \\
GILA & 3,121 & 0.002 & 0.011 & 0.000 & 0.116 & 835 & 0.251 & 0.419 & 0.002 & 2.585 \\
CDSN & 3,121 & 99.230 & 16.791 & 57.525 & 101.902 & 835 & 107.086 & 105.264 & 41.526 & 652.845 \\
\hline
\end{tabular}

Description: This table presents descriptive statistics for Sample 1 and Sample 2 for the variables used to examine the value relevance of goodwill impairments. MVAL is the dependent variable of the multivariate OLS regression model, all the variables are deflated by year-end total ordinary shares outstanding. MVAL is the market capitalization of firm $i$ at $30^{\text {th }}$ April of year $(\mathrm{t}+1)$; BVAL is the book value of equity minus the carrying value of goodwill of firm $i$ at $31^{\text {st }}$ December of year ( $\mathrm{t}$ ); PTP is the sum of the pre-tax profit and the reported goodwill impairment loss of firm $i$ at $31^{\text {st }}$ December of year (t); ECVGW is the sum of the carrying value of goodwill and the reported goodwill impairment loss of firm $i$ at $31^{\text {st }}$ December of year (t); GILA is the reported goodwill impairment loss of firm $i$ at $31^{\text {st }}$ December of year ( $\mathrm{t}$ ), expressed as a positive number. GILA is zero for firms which do not report goodwill impairments; $C D S N_{i}$ is the market price at $30^{\text {th }}$ April of year $(\mathrm{t}+1)$ of the 5 years-maturity CDS of the country where company $i$ operates.

Table 3 shows Pearson correlation coefficients and their statistical significance (the P Value, below in brackets) for the variables included in the ordinary least squares regression model for both Sample 1 and Sample 2. As we expected, BVAL, PTP, ECVGW and CDSN are characterized by a highly significant correlation coefficient for both samples; however, in both cases the Pearson correlation for GILA is near to zero and not significant. The level of correlation between explanatory variables is quite low, between zero and the value observed for BVAL-PTP in the second sample (0.616). Should be noticed that the new variable CDSN results is highly correlated with the dependent variable and not correlated with the other regressors.

Table 3. Pearson correlation coefficients for sample 1 and sample 2

\begin{tabular}{|c|c|c|c|c|c|c|c|c|c|c|c|c|}
\hline \multirow{2}{*}{$\begin{array}{l}\text { Sample } \\
\text { Variable } \\
\end{array}$} & \multicolumn{6}{|c|}{ Sample 1} & \multicolumn{6}{|c|}{ Sample 2} \\
\hline & MVAL & BVAL & РTP & ECVGW & GILA & CDSN & MVAL & BVAL & PTP & ECVGW & GILA & $\mathrm{CDSN}$ \\
\hline \multirow[t]{2}{*}{ MVAL } & 1.000 & & & & & & 1.000 & & & & & \\
\hline & - & & & & & & - & & & & & \\
\hline \multirow[t]{2}{*}{ BVAL } & 0.543 & 1.000 & & & & & 0.690 & 1.000 & & & & \\
\hline & $(0.000)$ & - & & & & & $(0.000)$ & - & & & & \\
\hline \multirow[t]{2}{*}{ PTP } & 0.657 & 0.382 & 1.000 & & & & 0.759 & 0.616 & 1.000 & & & \\
\hline & $(0.000)$ & $(0.000)$ & - & & & & $(0.000)$ & $(0.000)$ & - & & & \\
\hline \multirow[t]{2}{*}{ ECVGW } & 0.396 & -0.008 & 0.370 & 1.000 & & & 0.615 & 0.331 & 0.558 & 1.000 & & \\
\hline & $(0.000)$ & $(0.665)$ & $(0.000)$ & - & & & $(0.000)$ & $(0.000)$ & $(0.000)$ & - & & \\
\hline \multirow[t]{2}{*}{ GILA } & -0.011 & 0.013 & -0.027 & 0.122 & 1.000 & & 0.032 & 0.034 & -0.002 & 0.264 & 1.000 & \\
\hline & $(0.527)$ & $(0.486)$ & $(0.136)$ & $(0.000)$ & - & & $(0.353)$ & $(0.329)$ & $(0.956)$ & $(0.000)$ & - & \\
\hline \multirow[t]{2}{*}{ CDSN } & -0.093 & -0.026 & -0.018 & -0.011 & 0.041 & 1.000 & -0.122 & -0.029 & -0.032 & -0.058 & -0.020 & 1.000 \\
\hline & $(0.000)$ & $(0.145)$ & $(0.315)$ & $(0.537)$ & $(0.021)$ & - & $(0.000)$ & $(0.401)$ & $(0.357)$ & $(0.096)$ & $(0.562)$ & - \\
\hline
\end{tabular}

Description: This table shows the Pearson correlation coefficients for Sample 1 and Sample 2 for the variables used to examine the value relevance of goodwill impairments. Below the value of coefficients, in brackets, it is shown the P Value of each correlation. The definitions of variables are reported in Table 2 .

\subsection{Multivariate Regression Analysis Results}

The multivariate OLS regressions are performed using the Model defined in Equation (2), on the basis of data calculated as specified in Section 4.1. Besides the basic tests (F-statistic, adjusted $\mathrm{R}^{2}$, T-statistics), for each regression we run the following additional analyses: variance inflation factor ("VIF"), as an indicator of multicollinearity; White test for heteroscedasticity; Shapiro-Wilk test for the normality of residuals; the Ramsey 
RESET test using powers of the fitted values to assess the correct specification of the Model. For each explanatory variable $k$ we report the value of the coefficient $\beta_{k}$ and its T-statistic (below, in brackets), indicating with $(* * *)$ the estimates that are significant at a level of confidence of $99 \%$, with $(* *)$ the estimates that are significant at a level of confidence of $95 \%$ and with $(*)$ the estimates that are significant at a level of confidence of $90 \%$.

With reference to the UK company observations of Sample 1, Table 4 provides the results of the multivariate OLS regressions' estimates and significance tests for the whole sample and for its subsamples identified by sector and by GI\%.

Table 4. Multivariate OLS regression (equation 2) for sample 1: subsamples by sector and by GI\%

\begin{tabular}{|c|c|c|c|c|c|}
\hline Sample 1 & All & Financial & Non-Financial & GI $\% \leq 5 \%$ & GI\% $>5 \%$ \\
\hline $\mathrm{R}^{2}$ adjusted & $58.63 \%$ & $56.85 \%$ & $59.93 \%$ & $59.01 \%$ & $58.41 \%$ \\
\hline $\mathrm{N}$ & 3,121 & 510 & 2,611 & 2,979 & 133 \\
\hline F-statistic & $391.46^{* * *}$ & $76 * * *$ & $364.27 * * *$ & $393.06^{* * *}$ & $18.81 * * *$ \\
\hline P Value & $(0.00)$ & $(0.00)$ & $(0.00)$ & $(0.00)$ & $(0.00)$ \\
\hline \multirow[t]{2}{*}{$\beta_{0}$} & $0.898 * * *$ & $0.612 * * *$ & $0.977 * * *$ & $0.88^{* * *}$ & $0.843 * * *$ \\
\hline & $(10.62)$ & $(2.95)$ & $(10.68)$ & (10.16) & $(3.28)$ \\
\hline \multirow[t]{2}{*}{$\beta_{1}(\mathrm{BVAL})$} & $0.774 * * *$ & $0.65 * * *$ & $0.853 * * *$ & $0.765^{* * *}$ & $1.007 * * *$ \\
\hline & $(20.47)$ & $(11.82)$ & $(17.37)$ & $(20.01)$ & $(8.00)$ \\
\hline \multirow[t]{2}{*}{$\beta_{2}(\mathrm{PTP})$} & $3.202 * * *$ & $2.234 * * *$ & $3.441 * * *$ & $3.324 * * *$ & $0.979 * *$ \\
\hline & $(19.03)$ & $(7.62)$ & $(17.25)$ & (19.04) & $(2.18)$ \\
\hline \multirow[t]{2}{*}{$\beta_{3}(\mathrm{ECVGW})$} & $0.917 * * *$ & $1.058 * * *$ & $0.868 * * *$ & $0.933 * * *$ & $0.513^{*}$ \\
\hline & $(14.19)$ & $(7.14)$ & $(12.16)$ & $(14.12)$ & $(1.90)$ \\
\hline \multirow[t]{2}{*}{$\beta_{4}$ (GILA) } & $-4.961 * * *$ & -1.187 & $-5.455 * * *$ & $-18.92 * *$ & 2.004 \\
\hline & $(-2.85)$ & $(-0.33)$ & $(-2.78)$ & $(-2.54)$ & $(0.73)$ \\
\hline \multirow[t]{2}{*}{$\beta_{5}(\mathrm{CDSN})$} & $-0.007 * * *$ & -0.002 & $-0.008 * * *$ & $-0.007 * * *$ & $-0.01 * * *$ \\
\hline & $(-6.56)$ & $(-0.98)$ & $(-7.17)$ & $(-6.20)$ & $(-2.93)$ \\
\hline Multicollinearity (VIF) & 1.170 & 1.130 & 1.200 & 1.190 & 1.390 \\
\hline Heteroscedasticity & 349.870 & 73.350 & 297.870 & 334.950 & 27.370 \\
\hline White test (P Value) & $(0.00)$ & $(0.00)$ & $(0.00)$ & $(0.00)$ & $(0.13)$ \\
\hline Normality of residuals & 0.831 & 0.849 & 0.830 & 0.834 & 0.841 \\
\hline Shapiro-Wilk test (P Value) & $(0.00)$ & $(0.00)$ & $(0.00)$ & $(0.00)$ & $(0.00)$ \\
\hline Correct specification & 93.510 & 17.490 & 71.600 & 84.740 & 2.820 \\
\hline RESET test (P Value) & $(0.00)$ & $(0.00)$ & $(0.00)$ & $(0.00)$ & $(0.04)$ \\
\hline
\end{tabular}

Notes: *** significant at the 0.99 level, $* *$ significant at the 0.95 level and $*$ significant at the 0.90 level. See Table 2 for variables definitions.

In line with the results obtained by AbuGazaleh et al. (2012) and by Lapointe-Antunes et al. (2009), the basic tests of the model for the whole Sample 1 (All) and for Non-Financial firms show a high significance in terms of F-statistic (P Value $<0.00$ ), a good level of adjusted $\mathrm{R}^{2}(58.63 \%)$ and all the regressors (including GILA and the new variable CDSN) are significant at $99 \%$, with coefficient signs that are coherent with expectations. Nevertheless, the analysis of subsamples by sector and by GI\% shows that while the other regressors are almost always significant, GILA - that is the relevant variable for the purposes of this work - is not significant for Non-Financial firms and for GI\% > 5\% and its significance decreases to the $95 \%$ level of confidence for GI $\%$ < $5 \%$. Furthermore, for all the samples (Sample 1 and its subsamples), while there are no problems of multicollinearity (VIF < 1.39) and the heteroscedasticity is present but corrected using White's corrected variance and standard errors, the model shows problems of non-normality of residuals and possible misspecification. A higher level of significance and explanatory power is observed for companies whose GI\% is lower than or equal to $5 \%$.

It should be noted that, the impairment on goodwill is more value relevant when the percentage incidence of goodwill impairment at year (t) on the amount of goodwill at year (t-1) (GI) is less than 5\%. In other words, the results show that investors are more careful when low impairment losses are recognized.

With reference to the Non-Financial subsample, Figure 1 shows the Kernel density estimation of regression residuals with a normal density overlaid over the plot. 


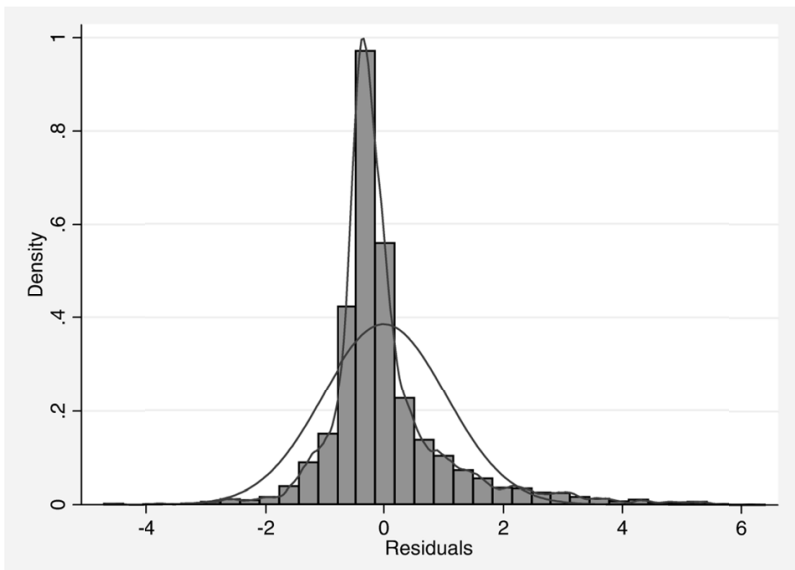

Figure 1. Kernel density estimate of residuals for non financial firms of sample 1 and normal density plot

The non-normality of residuals is evident also analyzing their normal probability plot shown in Figure 2, that deviates heavily from the normal distribution's straight line.

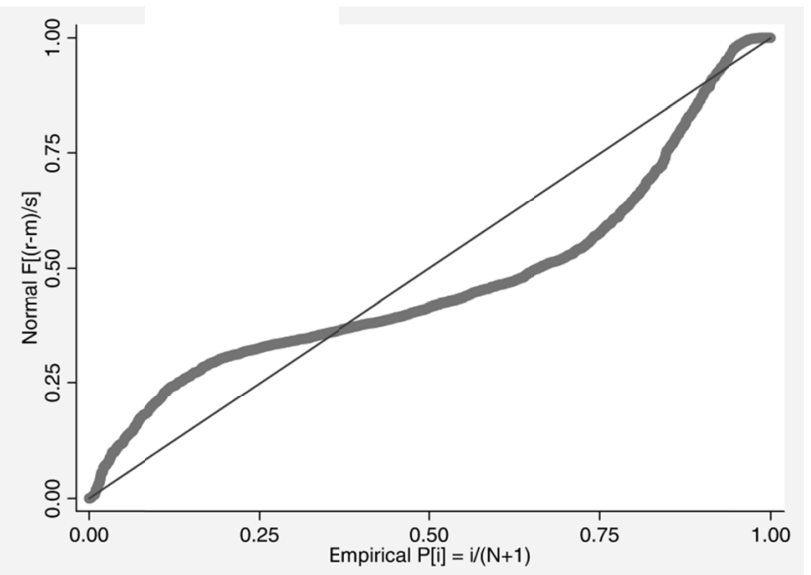

Figure 2. Normal probability plot of residuals for non financial firms of sample 1

Finally, despite the application of the Winsorization procedure to eliminate extreme observations for each variable of the Model, the Cook's distance graph shown in Figure 3 indicates that further analyses should be performed in order to identify influential observations (the horizontal line is the cut-off threshold equal to $4 / \mathrm{N}$ ).

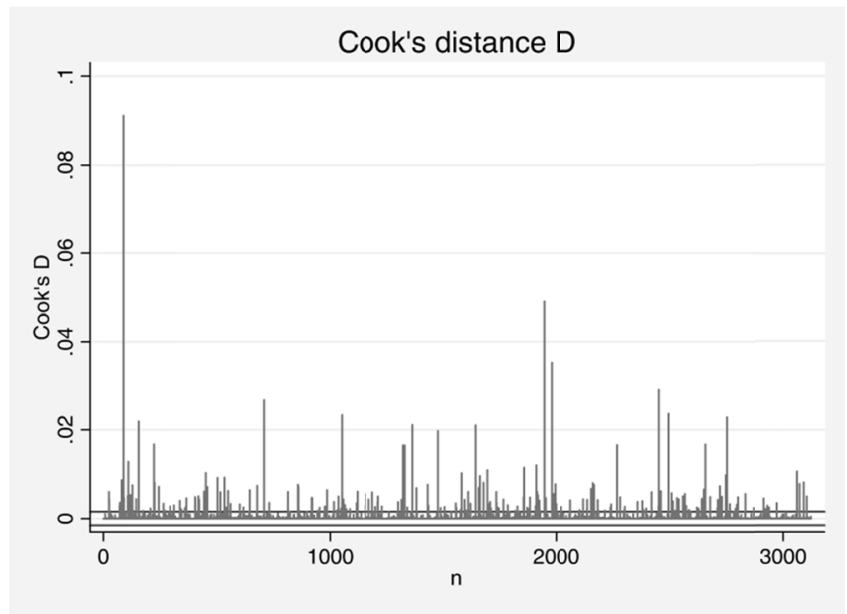

Figure 3. Cook's distances for non financial firms of sample 1 
The presence of influential observations can be detected also examining the DFITS graph shown in Figure 4, where DFITS $_{i}$ is the scaled differences between the estimates obtained by using all the data and the estimates obtained by setting the $\mathrm{i}$-th observation aside (the horizontal line is the cut-off threshold equal to $2 \sqrt{k / N}$ ).

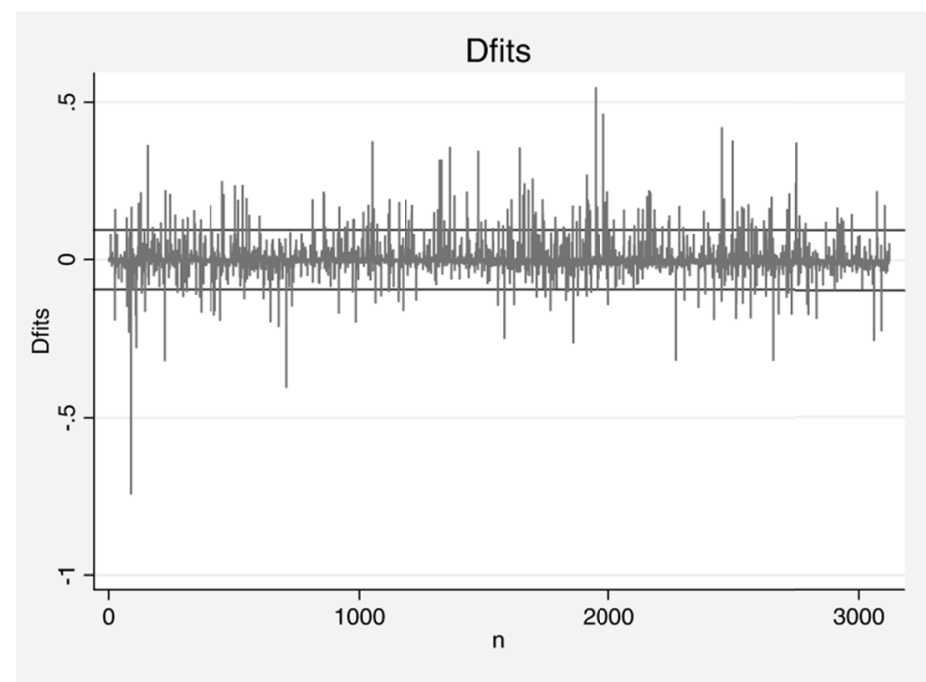

Figure 4. DFITS for Non financial firms of sample 1

Similarly, Figure 5 shows the DFBETAS for the same subsample, where $D F B E T A_{j, i}$ is determined with the same logic used for $D_{F I T S}$ but looking at the change in each regression coefficient rather than the fitted values (the horizontal lines are the cut-off thresholds equal to $\pm 2 \sqrt{N}$ ).

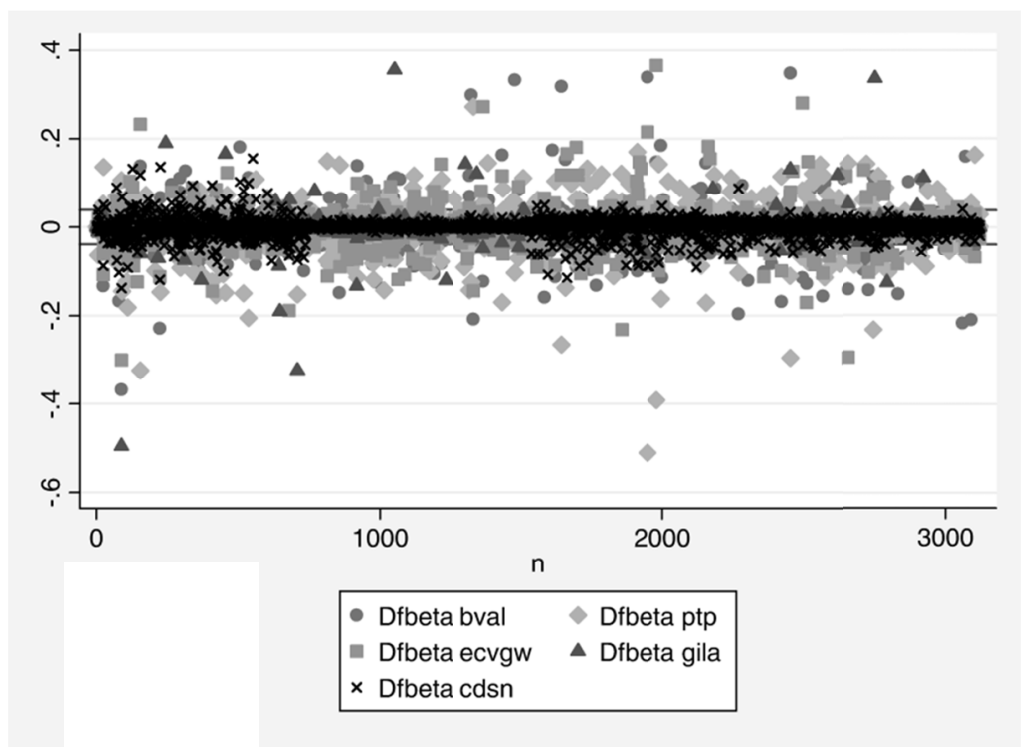

Figure 5. DBETAS for non financial firms of sample 1

Extending the analyses to other European nations and focusing only on write-downs observations, Table 5 reports the results of the multivariate OLS regression performed on Sample 2 and its subsamples, organized as in Table 4 by sector and by GI\%. 
Table 5. Multivariate OLS regression (equation 2) for sample 2: subsamples by sector and by GI\%

\begin{tabular}{llllll}
\hline Sample 2 & All & Financial & Non Financial & GI\% $\leq \mathbf{5 \%}$ & GI\%>5\% \\
\hline $\mathrm{R}^{2}$ adjusted & $72.03 \%$ & $76.80 \%$ & $72.42 \%$ & $76.13 \%$ & $61.80 \%$ \\
$\mathrm{~N}$ & 835 & 140 & 695 & 376 & 447 \\
F-statistic & $163.97^{* * *}$ & $31.99^{* * *}$ & $140.7 * * *$ & $113.98^{* * *}$ & $60.77^{* * *}$ \\
$\mathrm{P}$ Value & $(0.00)$ & $(0.00)$ & $(0.00)$ & $(0.00)$ & $(0.00)$ \\
\hline$\beta_{0}$ & $4.218^{* * *}$ & $2.49^{* * *}$ & $4.511^{* * *}$ & $4.417^{* * *}$ & $3.515^{* * *}$ \\
& $(9.50)$ & $(4.20)$ & $(8.63)$ & $(5.99)$ & $(6.37)$ \\
$\beta_{1}$ (BVAL) & $0.61^{* * *}$ & $0.664^{* * *}$ & $0.652^{* * *}$ & $0.483^{* * *}$ & $0.743^{* * *}$ \\
& $(7.74)$ & $(4.25)$ & $(6.49)$ & $(4.68)$ & $(5.22)$ \\
$\beta_{2}$ (PTP) & $2.636^{* * *}$ & 0.636 & $2.821^{* * *}$ & $3.8 * * *$ & $1.725^{* * *}$ \\
$\beta_{3}$ (ECVGW) & $(7.27)$ & $(1.30)$ & $(6.62)$ & $(6.82)$ & $(3.77)$ \\
$\beta_{4}$ (GILA) & $0.921^{* * *}$ & 1.011 & $0.859^{* * *}$ & $0.978^{* * *}$ & $0.454^{* *}$ \\
$\beta_{5}$ (CDSN) & $(7.82)$ & $(1.25)$ & $(6.91)$ & $(4.81)$ & $(2.10)$ \\
& $-2.366^{* *}$ & -1.645 & $-2.631^{* *}$ & $-16.535^{*}$ & 0.599 \\
\hline Multicollinearity (VIF) & $(-2.10)$ & $(-0.76)$ & $(-2.05)$ & $(-1.90)$ & $(0.39)$ \\
Heteroscedasticity & $-0.013^{* * *}$ & $-0.013 * * *$ & $-0.012^{* * *}$ & $-0.017 * * *$ & $-0.01 * * *$ \\
White test (P Value) & $(-6.52)$ & $(-4.85)$ & $(-5.24)$ & $(-4.44)$ & $(-5.57)$ \\
Normality of residuals & 1.500 & 1.790 & 1.530 & 1.820 & 1.610 \\
Shapiro-Wilk test (P Value) & 173.270 & 85.160 & 165.750 & 98.140 & 158.780 \\
Correct specification & $(0.00)$ & $(0.00)$ & $(0.00)$ & $(0.00)$ & $(0.00)$ \\
RESET test (P Value) & 0.799 & 0.726 & 0.812 & 0.867 & 0.722 \\
\hline
\end{tabular}

Notes: ${ }^{* *}$ significant at the 0.99 level, ${ }^{* *}$ significant at the 0.95 level and $*$ significant at the 0.90 level. See Table 2 for variables definitions.

The Model shows good results in terms of basic tests and VIF, but GILA is the only regressor that is always not significant at a level of confidence of $99 \%$, resulting significant at a level of $95 \%$ only for the All and the Non-Financial samples. Furthermore, as for Sample 1, the Model always fails the Shapiro-Wilk test and the RESET test.

Focusing on Non Financial firms - that are the ones used by AbuGhazaleh et al. (2012) and for which our Model obtains the best results - Table 6 shows the multivariate OLS regression output for the Non-Financial firms of Sample 2 organized by country and by year. Portugal and Spain are excluded from the single country-analyses as their sample sizes are too low.

Consistent with AbuGhazaleh et al. (2012), we refer only to non-financial firms, because: a) the crisis has particularly affected the financial sector; and b) the different business model should have a significant impact on the results. Furthermore, especially after the entry into force of the Basel regulation, the main balance sheet items considered by market operators for valuing investments in the financial sector are the ones related to the regulatory capital, which do not include the value of goodwill. Hence, as confirmed by the results shown in Table 4 and Table 5, we expect GILA to be non-significant for financial firms.

With reference to Table 6, once again for each sub-sample the Model obtains good results in terms of basic statistics (F-statistic, adjusted $\mathrm{R}^{2}$, VIF), but the assumptions of normality of residuals and correct specification of the model are not verified in almost all the cases. Furthermore, the single-country analysis and the single-year analysis show that the individual significance of regressors is never verified for all the explanatory variables together at the same time, nor for the "basic" ones that are BVAL, PTP and ECVGW. As we expected, since it assumes only four values (the annual prices at $30^{\text {th }}$ April of the years from 2009 to 2012, that is of year $t+1$ for $t$ from 2008 to 2011), in single-country regressions the variable $C D S N$ is not significant, while in multiple country analyses - that considers the evolution of CDS prices during the Period - it proves to be significant information for estimating MVAL. On the other hand, GILA, that is the relevant variable for the purposes of this work, turns out to be non-significant in most of the cases examined. In particular, it is significant at a level of confidence of $99 \%(95 \%)$ in only $22.2 \%(27.8 \%)$ of cases - considering the analyses performed on both Sample 1 and Sample 2. 
Table 6. Multivariate OLS regression (equation 2) for sample 2: subsamples by country and by year, only non financial firms

\begin{tabular}{|c|c|c|c|c|c|c|c|c|}
\hline \multirow[t]{2}{*}{ Sample 2} & \multicolumn{8}{|c|}{ Non Financial } \\
\hline & France & Germany & Italy & United Kingdom & 2008 & 2009 & 2010 & 2011 \\
\hline $\mathrm{R}^{2}$ adjusted & $72.10 \%$ & $65.65 \%$ & $35.62 \%$ & $63.40 \%$ & $69.36 \%$ & $75.06 \%$ & $81.69 \%$ & $69.85 \%$ \\
\hline $\mathrm{N}$ & 218 & 183 & 78 & 173 & 191 & 176 & 161 & 167 \\
\hline F-statistic & $109.08 * * *$ & $28.33^{* * *}$ & $9.26^{* * *}$ & $7.48^{* * *}$ & $36.44 * * *$ & $49.5^{* * *}$ & $64.65^{* * *}$ & $33.86^{* * *}$ \\
\hline P Value & $(0.00)$ & $(0.00)$ & $(0.00)$ & $(0.00)$ & $(0.00)$ & $(0.00)$ & $(0.00)$ & $(0.00)$ \\
\hline \multirow[t]{2}{*}{$\beta_{0}$} & $7.627 * * *$ & -2.094 & $2.623 * * *$ & 0.881 & $4.772 * * *$ & $6.713 * * *$ & $5.314^{* * *}$ & $4.108 * * *$ \\
\hline & $(4.68)$ & $(-0.87)$ & $(3.38)$ & $(0.92)$ & $(2.84)$ & $(5.29)$ & $(5.34)$ & $(4.34)$ \\
\hline \multirow[t]{2}{*}{$\beta_{1}(\mathrm{BVAL})$} & $0.431 * * *$ & $1.256^{* * *}$ & $0.621 * * *$ & $0.81 * * *$ & $1.006 * *$ & $0.674 * * *$ & $0.514 * * *$ & $0.25^{*}$ \\
\hline & $(4.64)$ & $(4.67)$ & $(4.45)$ & $(2.89)$ & $(2.47)$ & $(5.64)$ & $(4.43)$ & $(1.74)$ \\
\hline \multirow{2}{*}{$\beta_{2}(\mathrm{PTP})$} & $3.459 * * *$ & $2.138^{* *}$ & 0.8 & $3.617 * * *$ & $1.615^{*}$ & $2.729 * * *$ & $4.134 * * *$ & $4.283^{* * *}$ \\
\hline & $(6.99)$ & $(2.40)$ & $(1.45)$ & $(4.15)$ & $(1.79)$ & $(4.22)$ & $(5.70)$ & $(4.33)$ \\
\hline \multirow[t]{2}{*}{$\beta_{3}(\mathrm{ECVGW})$} & $0.885^{* * *}$ & $0.9^{* * *}$ & $0.509^{* *}$ & 0.367 & $0.525 * * *$ & $1.165^{* * *}$ & $0.854 * * *$ & $0.65^{*}$ \\
\hline & $(6.89)$ & $(2.65)$ & $(2.57)$ & (1.64) & $(2.60)$ & $(6.85)$ & $(4.55)$ & (1.87) \\
\hline \multirow[t]{2}{*}{$\beta_{4}$ (GILA) } & $-6.611 * * *$ & 2.504 & -0.367 & 0.696 & $-2.866^{* * *}$ & $-3.494 *$ & -3.318 & 1.705 \\
\hline & $(-4.70)$ & $(0.89)$ & $(-0.25)$ & $(0.70)$ & $(-2.69)$ & $(-1.79)$ & $(-1.14)$ & $(0.38)$ \\
\hline \multirow[t]{2}{*}{$\beta_{5}(\mathrm{CDSN})$} & -0.024 & $0.087 * *$ & -0.004 & -0.002 & $-0.032 * *$ & $-0.039 * * *$ & $-0.01 * * *$ & $-0.01 * * *$ \\
\hline & $(-1.54)$ & $(2.00)$ & $(-1.55)$ & $(-0.13)$ & $(-2.38)$ & $(-4.15)$ & $(-2.75)$ & $(-3.20)$ \\
\hline Multicollinearity (VIF) & 1.500 & 1.320 & 1.490 & 1.350 & 1.510 & 1.570 & 1.710 & 1.690 \\
\hline Heteroscedasticity & 37.180 & 112.830 & 30.380 & 106.590 & 154.360 & 37.990 & 37.300 & 58.170 \\
\hline White test (P Value) & $(0.01)$ & $(0.00)$ & $(0.06)$ & $(0.00)$ & $(0.00)$ & $(0.01)$ & $(0.01)$ & $(0.00)$ \\
\hline Normality of residuals & 0.914 & 0.872 & 0.882 & 0.748 & 0.771 & 0.866 & 0.901 & 0.819 \\
\hline Shapiro-Wilk test (P Value) & $(0.00)$ & $(0.00)$ & $(0.00)$ & $(0.00)$ & $(0.00)$ & $(0.00)$ & $(0.00)$ & $(0.00)$ \\
\hline Correct specification & 4.510 & 6.410 & 2.340 & 68.850 & 10.060 & 10.900 & 11.630 & 4.780 \\
\hline RESET test (P Value) & $(0.00)$ & $(0.00)$ & $(0.08)$ & $(0.00)$ & $(0.00)$ & $(0.00)$ & $(0.00)$ & $(0.00)$ \\
\hline
\end{tabular}

Notes: $* * *$ significant at the 0.99 level, $* *$ significant at the 0.95 level and $*$ significant at the 0.90 level. See Table 2 for variables definitions.

We observe that in 2008, that is the year during which it began the current financial crisis, GILA is significant at the $99 \%$ level, while it is not significant in 2009 (only at 90\%) and in the following years. A relevant element to be noticed is the gradual decrease with time of GILA's T-statistics, that show a marked downward trend from 2008 (highly significant) to 2011 (not significant). Finally, it is interesting to notice that France is characterized by the highest level of significance (F-statistic and all the T-statistics with P Values $<0.00$ ) and explanatory power (adjusted $\mathrm{R}^{2}=72.10 \%$ ) of the Model among the nations, with also GILA significant at the $99 \%$ level.

\section{Conclusions}

Our analyses evidences that the model obtains good results in terms of basic statistics, such as the F-statistic, adjusted $\mathrm{R}^{2}$ and variance inflation factor. With reference to the two macro-samples, also the T-statistics show a high individual significance of the regressors, including the one relating to the goodwill impairments and the new one relating to the sovereign default risk of each country. However, additional tests show that some basic assumptions of the ordinary least squares regression method are not verified, as we detect problems of non-normality of residuals and misspecification. Furthermore, the analyses of subsamples evidence that the validity and the effectiveness of the model varies significantly across countries, sectors and groups of firms characterized by different levels of relative importance of goodwill impairments. Finally, we notice that in most cases the goodwill impairment variable is non-significant.

This study contributes to the existing literature by providing new evidence about the effective value relevance of goodwill impairments in recent years for a wide range of countries, sectors and categories of companies that operate in the European Union area. We also detect a new, significant explanatory variable for estimating the stock market price of companies using a model that is widely known in literature, performing in-depth econometric analyses in order to assess its validity. Our findings evidence that, in general, the model suffers from some econometric shortcomings and the results of the multivariate regressions analyses raise questions about the effective value relevance of goodwill impairments.

The empirical results show that French stock market, unlike the others considered, is more sensitive when a 
goodwill impairment loss is recognized. Consistent with prior studies, in other stock markets the empirical results reveal a significant negative association between reported goodwill impairment losses and market values, suggesting that these impairments are perceived by investors to reliably measure a decline in the value of goodwill and are incorporated in their firm valuation assessments.

In the light of the above considerations and consistent with empirical results, that do not show any significant association between the impairment loss on goodwill and the stock price, we believe that the value relevance of the impairment test on goodwill increases during periods of negative stress in financial markets. Moreover, although we tested the value relevance of goodwill impairments for a sample of firms that should be harmonized since 2005 , the empirical results evidence that country-specific factors have a significant influence on the investment decisions of market operators.

In addition, the empirical results show that a financial crisis like the one that began in 2008 is able to reduce the differences - in terms of investors' sensitivity to the main balance sheet items of firms - due to country-specific factors. In particular, the results evidence that during periods of crisis the attention of investors to - and, consequently, the value relevance of - goodwill impairments increases.

This would lead us to believe that the country differences are mitigated or less tangible when the economic cycle is stressed.

For these reasons, with reference to 2008 , the model, mutatis mutandis, obtains the same results for all countries/stock markets over this period. This is also supported by the empirical results on 2009 that show how the association between the goodwill impairment and the market value was starting to decrease, probably, because the investors' attention was also decreasing.

Further investigation could be done in order to empirically test if and how the country-specific factors influence the differences that we note in this work when referring to France. Furthermore, on the basis of the results that we obtain for 2008 , it would be appropriate to investigate the circumstances that can lessen the differences due to the country-specific factors.

\section{References}

Aboody, D., Hughes, J., \& Liu, J. (2002). Measuring value relevance in a (Possibly) inefficient market. Journal of Accounting Research, 40(4), 965-986. http://dx.doi.org/10.1111/1475-679X.00078

AbuGhazaleh, N. M., Al-Hares, O. M., \& Haddad, A. E. (2012). The Value Relevance of goodwill impairments: UK evidence. International Journal of Economics and Finance, 4(4), 206-216. http://dx.doi.org/10.5539/ijef.v4n4p206

Accounting Standards Board. (1997). Financial Reporting Standard 10. Goodwill and Intangible Assets.

Accounting Standards Board. (1998). Financial Reporting Standard 11. Impairment of Fixed Assets and Goodwill.

Alia, M., \& Branson, J. (2011). The effect of environmental factors on accounting diversity. A literature review. Retrieved from SSRN: http://ssrn.com/abstract=1780479, working paper.

Amodeo, D. (1960). Avviamento e riserva occulta: un accostamento. studi di Ragioneria e tecnica economica, scritti in onore del Prof., Alberto Ceccherelli, Le Monnier, Firenze.

Ardemani, E. (1957). L'avviamento dell'impresa. Marzorati, Milano.

Ashiq, A., \& Lee-Seok, H. (2000). Country-Specific Factors Related to Financial Reporting and the Value Relevance of Accounting Data. Journal of Accounting Research, 38(1), 1-21.

Barret, M. J., Beaver, W. H., Cooper, W. W., Milburn, J. A., Solomons, D., \& Tweedie, D. P. (1991). American Accounting Association Committee on Accounting and Auditing Measurement, 1989 -90. Accounting Horizons, 5(3), 81-105.

Barth, M. E. (2000). Valuation-based accounting research: Implications for financial reporting and opportunities for future research. Accounting and Finance, 40(1), 7-31. http://dx.doi.org/10.1111/1467-629X.00033

Barth, M. E., \& Clinch, G. (1998). Revalued financial, tangible, and intangible assets: associations with share prices and non-market-based value estimates. Journal of Accounting Research, 36(supplement), 199-233. http://dx.doi.org/10.2307/2491314

Barth, M. E., Beaver, W. H., \& Landsman, W. R. (2001). The relevance of the value relevance literature for financial accounting standard setting: another view. Journal of Accounting and Economics, 31, 77-104. 
http://dx.doi.org/10.1016/S0165-4101(01)00019-2

Barth, M. E., Cram, D. P., \& Nelson, K. K. (2001). Accruals and the prediction of future cash flows. The Accounting Review, 76(1), 27-58. http://dx.doi.org/10.2308/accr.2001.76.1.27

Bartov, E., Lindahl, F. W., \& Ricks, W. E. (1998). Stock Price behavior around announcements of write-offs. Review of Accounting Studies, 3(4), 327-346. http://dx.doi.org/10.1023/A:1009644800963

Barua, A., Legoria, J., \& Moffitt, J. S. (2006). Accruals Management to Achieve Earnings Benchmarks: A Comparison of Pre-managed Profit and Loss Firms. Journal of Business Finance and Accounting, 33(5 \& 6), 653-670. http://dx.doi.org/10.1111/j.1468-5957.2006.00017.x

Beattie, V. (2005). Moving the financial accounting research front forward: the UK contribution. British Accounting Review, 37, 85-114. http://dx.doi.org/10.1016/j.bar.2004.09.004

Beatty, A., \& Weber, J. (2006). Accounting discretion in fair value estimates: an examination of SFAS 142 goodwill impairments. Journal of Accounting Research, 44(2), 257-88. http://dx.doi.org/10.1111/j.1475-679X.2006.00200.x

Beaver, W. H. (2002). Perspectives on Recent Capital Market Research. Accounting Review, 77(2), 453-474. http://dx.doi.org/10.2308/accr.2002.77.2.453

Beisland, L. A. (2008). Essays on the Value Relevance of Accounting Information. Dissertation.

Bens, D. A., \& Heltzer, W. (2004). The Information Content and Timeliness of Fair Value Accounting: An Examination of Goodwill Write-offs Before, During and After Implementation of SFAS 142. Working paper. University of Chicago.

Brown, S., Lo, K., \& Lys, T. (1999). Use of R2 in accounting research: measuring changes in value relevance over the last four decades. Journal of Accounting and Economics, 28, 83-115. $\mathrm{http}: / / \mathrm{dx}$.doi.org/10.1016/S0165-4101(99)00023-3

Capaldo, P. (1998). Reddito, capitale e bilancio di esercizio. Una introduzione. Giuffrè, Milano.

Chen, P., \& Zhang, G. (2007). How do accounting variables explain stock price movements? Theory and evidence. Journal of Accounting and Economics, 43, 219-244. http://dx.doi.org/10.1016/j.jacceco.2007.01.001

Colley, J. R., \& Volkan, A. G. (1988). Accounting for Goodwill. Accounting Horizons, March, 35-41.

Collins, D., Maydew, E., \& Weiss, I. (1997). Changes in the value and relevance of earnings and book values over the past forty years. Journal of Accounting and Economics, 24, 39-67. $\mathrm{http}: / / \mathrm{dx}$.doi.org/10.1016/S0165-4101(97)00015-3

D'ippolito, T. (1963). L'avviamento. La valutazione delle aziende avviate e di quote-parti di esse. L'avviamento commerciale e l'avviamento imponibile fiscalmente. Abbaco, Palermo.

Dahmash, F., Durand, R., \& Watson, J. (2009). The value relevance and reliability of reported goodwill and identifiable intangible assets. British Accounting Review, 41, 120-137. http://dx.doi.org/10.1016/j.bar.2009.03.002

Degeorge, F., Patel, J., \& Zeckhauser, R. (1999). Earnings management to exceed thresholds. Journal of Business, 72(1), 1-33. http://dx.doi.org/10.1086/209601

Dumontier, P., \& Raffournier, B. (2002). Accounting and capital markets: a survey of the European evidence. European Accounting Review, 11(1), 119-151. http://dx.doi.org/10.1080/09638180220124761

Duvall, L., Jennings, R., Robinson, J., \& Thompson, R. B. (1992). Can Investors Unravel the Effects of Goodwill? Accounting Horizons, 6(2), 1-14.

Elliott, J. A., \& Shaw, W. H. (1998). Write-offs as accounting procedures to manage perceptions. Journal of Accounting Research, 26(Supplement), 91-119.

Francis, J., \& Schipper, K. (1999). Have Financial Statements Lost Their Relevance? Journal of Accounting Research, 37(2), 319-352. http://dx.doi.org/10.2307/2491412

Francis, J., Hanna, J., \& Vincent, L. (1996). Causes and effects of discretionary asset write-offs. Journal of Accounting Research, 34(Supplement), 117-134. http://dx.doi.org/10.2307/2491429

Goodwin, J., \& Ahmed, K. (2006). Longitudinal value relevance of earnings and intangible assets: evidence from Australian firms. Journal of International Accounting, Auditing and Taxation, 15, 72-91. 
http://dx.doi.org/10.1016/j.intaccaudtax.2006.01.005

Gray, S. J. (1988). Towards a Theory of Cultural Influence on the development of Accounting Systems Internationally. Abacus, 24(1), 1-15. http://dx.doi.org/10.1111/j.1467-6281.1988.tb00200.x

Guatri, L. (1957). L'avviamento d'impresa. Un modello quantitativo per l'analisi e la misurazione del fenomeno. Giuffrè, Milano.

International Accounting Standards Board, International Accounting Standard 36 (revised). Impairment of Assets.

International Accounting Standards Board, International Financial Reporting Standard 3, Business Combinations.

International Accounting Standards Board, International Financial Reporting Standard 38, Intangible Assets.

Jaggi, B., \& Low, P. Y. (2000). Impact of Culture, Market forces, and Legal System on financial Disclosures. The International Journal of Accounting, 35(4), 495-519. http://dx.doi.org/10.1016/S0020-7063(00)00076-5

Jennings, R., LeClere, M., \& Thompson, R. (2001). Goodwill Amortization and the Usefulness of Earnings. Financial Analysts Journal, 57(5), 20-28. http://dx.doi.org/10.2469/faj.v57.n5.2478

Kothari, S. P. (2001). Capital markets research in Accounting. Journal of Accounting and Economics, 31(1/3), 105-231. http://dx.doi.org/10.1016/S0165-4101(01)00030-1

Kothari, S. P., \& Zimmerman, J. L. (1995). Price and return models. Journal of Accounting and Economics, 20(2), 155-192. http://dx.doi.org/10.1016/0165-4101(95)00399-4

Laghi, E. (1994). L'ammortamento dell'avviamento. Aspetti economici, civilistici e contabili. Giappichelli, Torino.

Laghi, E. (2006). L'armonizzazione contabile via IAS/IFRS: prime riflessioni sull'evoluzione della disciplina in materia di bilancio delle società, Giappichelli, Torino.

Lapointe-Antunes, P., Cormier, D., \& Magnan, M. (2009). Value relevance and timeliness of transitional goodwill-impairment losses: evidence from Canada. International Joumal of Accounting, 44(1), 56-78. http://dx.doi.org/10.1016/j.intacc.2008.12.006

Lev, B., \& Zarowin, P. (1999). The Boundaries of Financial Reporting and How to Extend Them. Journal of Accounting Research, 37(2), 353-385. http://dx.doi.org/10.2307/2491413

Ma, R., \& Hopkins, R. (1988). Goodwill - An example of puzzle-solving in accounting. Abacus, 24(1), 75-85. http://dx.doi.org/10.1111/j.1467-6281.1988.tb00204.x

Markarian, G., Pozza, L., \& Prencipe, A. (2008). Capitalization of R\&D costs and earnings management: Evidence from Italian listed companies. International Journal of Accounting, 43(3), 246-267. http://dx.doi.org/10.1016/j.intacc.2008.06.002

Marquardt, C. A., \& Wiedman, C. I. (2004). The effect of earnings management on the value relevance of accounting information. Journal of Business Finance and Accounting, 31(3/4), 297-332. http://dx.doi.org/10.1111/j.0306-686X.2004.00541.x

Massoud, M. F., \& Raibom, C. A. (2003). Accounting for Goodwill: are we better off? Review of Business, 24(2), 26-32.

Miller, M. C. (1973). Goodwill-an aggregation issue. Accounting Review, 48(2), 280-289.

Moehrle, S. R., Reynolds-Moehrle, J. A., \& Wallace, J. S. (2001). How informative are earnings numbers that exclude goodwill amortization? Accounting Horizons, 5(3), 243-255. http://dx.doi.org/10.2308/acch.2001.15.3.243

Nobes, C. (1998). Towards a General Model of the Reasons for International Differences in Financial Reporting. Abacus, 34(2), 162-186. http://dx.doi.org/10.1111/1467-6281.00028

Ohlson, J. (1995). Earnings, book values, and dividend in equity valuation. Contemporary Accounting Research, 11(2), 661-687. http://dx.doi.org/10.1111/j.1911-3846.1995.tb00461.x

Oliveira, L., Rodrigues, L. L., \& Craig, R. (2010). Intangible assets and value relevance: Evidence from the Portuguese stock exchange. British Accounting Review, 42, 241-252. http://dx.doi.org/10.1016/j.bar.2010.08.001

Organismo Italiano di Contabilità. Accounting Standard OIC n. 24, Immobilizzazioni Immateriali. 
Paoloni, M. (1988). L'avviamento nella IV Direttiva CEE e nello schema di legge delegata. Alcune considerazioni. Rivista Italiana di Ragioneria e di Economia Aziendale, n. 9-10 e n. 11-12.

Papadaki, A., \& Siougle, G. (2007). Value relevance of price, earnings and book values in the Athens Stock Exchange. Managerial Finance, 33(5), 309-320. http://dx.doi.org/10.1108/03074350710739597

Ramanna, K. (2008). The implications of unverifiable fair-value accounting: Evidence from political economy of goodwill accounting. Journal of Accounting and Economics, 45(2/3), 253-281. http://dx.doi.org/10.1016/j.jacceco.2007.11.006

Strong, J. S., \& Meyer, J. R. (1987). Asset write-downs: managerial incentives and security returns. The Journal of finance, 42(3), 643-661. http://dx.doi.org/10.1111/j.1540-6261.1987.tb04574.x

Subramanyam, K. R., \& Venkatachalam, M. (2007). Earnings, Cash Flows, and Ex Post Intrinsic Value of Equity. The Accounting Review, 82(2), 457-481. http://dx.doi.org/10.2308/accr.2007.82.2.457

Swanson, Z. L., Singer, R., \& Downs, A. (2007). Goodwill Impairment: A Comparative Country Analysis. EUFIN conference presentation.

Watts, R. L. (2003). Conservatism in Accounting. Part 1: Explanations and Implications. Accounting Horizons, 17(3), 207-221. http://dx.doi.org/10.2308/acch.2003.17.3.207

Xu, W., Anandarajan, A., \& Curatola, A. (2011). The value relevance of goodwill impairment. Research in Accounting Regulation, 23(2), 145-148. http://dx.doi.org/10.1016/j.racreg.2011.06.007

Zanda, G. (2007). Il bilancio delle società. Lineamenti teorici e modelli di redazione. Giappichelli, Torino.

Note

Note 1. For Italy: OIC n. 24; civil code art. 2426 6); for UK: FRS n. 10.

\section{Copyrights}

Copyright for this article is retained by the author(s), with first publication rights granted to the journal.

This is an open-access article distributed under the terms and conditions of the Creative Commons Attribution license (http://creativecommons.org/licenses/by/3.0/). 